\title{
Amiodarone and tetracyclines has synergistic antibacterial effect
}

\author{
Batai IZ', Szabo A², Gyorffy O', Barkoczy R², Kerenyi M², Batai I.' \\ ${ }^{1}$ Department of Anaesthesia and Intensive Care, ${ }^{2}$ Department of Medical Microbiology \\ University of Pécs, Hungary
}

\section{Introduction}

Patients treated in intensive care units usually require the intravenous co-administration of drugs with different mechanism of action for acute and chronic illness, infection, pain relief, and sedation. Nonantibiotics may have synergistic antimicrobial effect of an antibiotic in vitro (1). The antifungal synergism of amiodarone and an azole compound for Candida albicans is already known (2). In this study we investigated the impact of amiodarone on the bactericidal effect of antibiotics.

\section{Methods}

Amiodarone infusion was contaminated with low colony forming units (cfu) of standard bacterial strains (Staphylococcus aureus ATCC 25923, Escherichia coli ATCC 25922, Pseudomonas aeruginosa ATCC 27853) separately and bacterial count was checked at intervals. Minimal inhibitory concentration (MIC) of the drugs were determined (according to CLSI) and compared with serum concentration. Checkerboard method (Figure 1) was used for investigation of combined effect of amiodarone and antibiotics (see Table 1) with different mechanism of action. We determined the fractional inhibitory concentration index what is the predictor of synergism.

$$
\Sigma \mathrm{FIC}=\mathrm{FIC}_{\mathrm{A}}+\mathrm{FIC}_{\mathrm{B}}=\frac{\mathrm{MIC}_{\mathrm{A} \text {, lomb. }}}{\mathrm{MIC}_{\mathrm{A}}}+\frac{\mathrm{MIC}_{\mathrm{B}, \text { komb. }}}{\mathrm{MIC}_{\mathrm{B}}}
$$

A: antibiotic

B: non-antibiotic

FIC $\leq 0,5$ - synergistic

$0,5<$ FIC $<4-$ non synergistic

$4 \leq \mathrm{FIC}$ - antagonistic

Table 1 Antibiotics and non-antibiotic Amoxicillin+clavulanic acid (Augmentin ${ }^{\circledR}$ GlaxoSmithKline Beecham) Cefotaxime (Cloforan ${ }^{\circledR}$ Sanofi-Aventis) Imipenem+cilastin (Tienam ${ }^{\circledR}$ MDS) Gentamicin (Chinoin)

Amikacin (Amikin ${ }^{\circledR}$ Bristol-Myers Squibb)

Ciprofloxacin (Ciprobay® Bayer Schering Pharma AG)

Oxytetracyclin (Békéscsaba Gyógyszerkiszerelő labor)

Chloramphenicol (University of Pécs, Pharmacy 345/03)

Amiodaron (Cordarone ${ }^{\circledR}$ Sanofi-Aventis) $-150 \mathrm{mg} / 3 \mathrm{ml}$ Diluted in $250 \mathrm{ml}$ of $5 \%$ glucose infusion
Figure 1. Checkerboard method

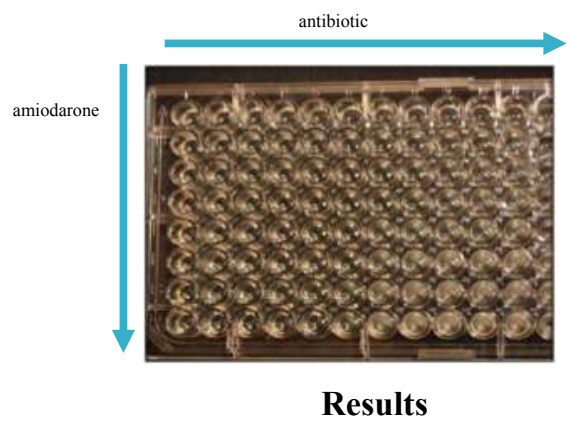

$5 \times 10^{3} \mathrm{cfu}$ bacteria did not survive in amiodarone infusion after 15 minutes. MIC levels of both drugs are higher than the serum concentration of drugs $(2,8 \mathrm{microg} / \mathrm{ml})$. There were synergistic antimicrobial effects of combined amiodarone and oxytetracycline against standard bacterial strains. (Table 2.-3.)

Table 2. Amiodarone MIC level

\begin{tabular}{|l|l|}
\hline Strains & Amiodarone MIC \\
\hline S. aureus & $200 \mathrm{microg} / \mathrm{ml}$ \\
\hline E. coli & $300 \mathrm{microg} / \mathrm{ml}$ \\
\hline P. aerugoinosa & $300 \mathrm{microg} / \mathrm{ml}$ \\
\hline
\end{tabular}

Table 3. Fractional inhibitory concentration indexes

\begin{tabular}{|l|l|l|l|l|l|l|}
\hline Amiodarone+ & amoxicillin & cefotaxime & imipenem & oxytetracyclin & gentamicin & ciprofloxacin \\
\hline S. aureus & $0.5-1.09$ & $0.06^{*}-0, .207^{*}$ & $0,144^{*}-0.54$ & $0,046^{*}-0,07^{*}$ & 1,256 & $0,167^{*}-0.635$ \\
\hline E. coli & $0,25^{*}-1.19$ & $1,65-3.16$ & $0,14^{*}-0.54$ & $0,07^{*}-0,245^{*}$ & 1,258 & $0,31^{*}-1.01$ \\
\hline P. aeruginosa & NA & $0,215^{*}-0,78$ & $0,043^{*}-0,14^{*}$ & $0,069^{*}-0,245^{*}$ & 0.636 & $0,312^{*}-1,249$ \\
\hline
\end{tabular}

FIC $\leq 0,5$ synergistic

\section{Conclusions}

Non-antibiotics might have antimicrobial synergistic effect with some antibiotics, thus they may contribute to the killing of pathogens when they are co-administrated. Further research is required whether there is any in vivo synergistic effect resemble for the above in vitro results.

References: (1) Nat Chem Biol 2011; 7: 348. (2) J Med Microbiol 2008; 57:457. 